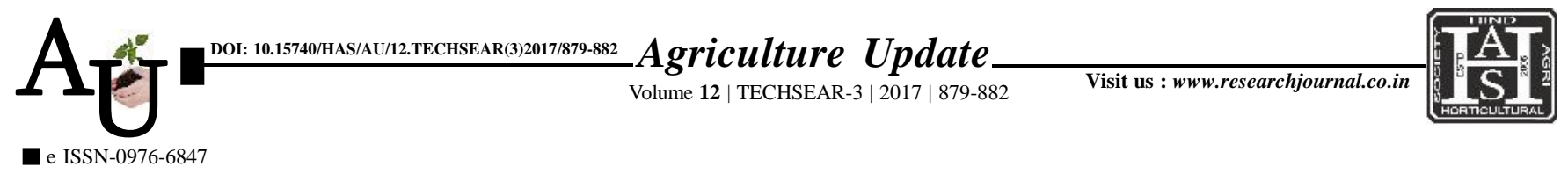

A ReVIEW :

\title{
Self incompatibility a mechanism for controlled pollination in vegetable crops
}

\author{
SHILPA KUMARI, ARCHANA ANOKHE AND RAHUL KUMAR
}

Article Chronicle:

Received :

13.07.2017;

Accepted :

28.07.2017

KeY Words:

Self incompatibility, Vegetable crops,

Cabbage, Tomato
SUMMARY : Self-incompatibility (SI) is a genetically controlled cell to cell recognition system that acts as abarrier to self-pollination in a wide range of vegetable crops like cabbage, cauliflower, tomato etc. Self-incompatibility is a major mechanism by which plants prevent self-fertilization and maintain genetic diversity. SI is estimated to occur in 30-50\% of flowering plant species. Several SI systems have now been identified. In all cases incompatible (self-) pollen is recognized by a highly specific genetically controlled mechanism that results in inhibition of the pollen in the stigma or style of the pistil.The use of SI in $\mathrm{F}_{1}$ hybrid production has major advantage over other methods. Use of SI in cole crops for hybrid seed production is commercialised till date in vegetable crops because availability of cost effective mechanism/method to produce large-scale F1 seeds utilizing selected parental lines is an important factor, which ultimately determines the commercial viability of the hybrid varieties.

How to cite this article : Kumari, Shilpa, Anokhe, Archana and Kumar, Rahul (2017). Self incompatibility a mechanism for controlled pollination in vegetable crops. Agric. Update, 12(TECHSEAR-3) : 879-882; DOI: 10.15740/HAS/AU/12.TECHSEAR(3)2017/879-882.
Author for correspondence :

\section{RAHUL KUMAR}

Division of Vegetable

Science, Indian

Agricultural Research

Institute, Pusa, NEW

DELHI (INDIA)

Email : rahulvegiari@

gmail.com

See end of the article for

authors' affiliations 